\title{
Recurrent multifocal conjunctival melanoma originated from preexisting pigmented nevus
}

\author{
Melanoma conjuntival multifocal recidivado originado \\ de nevus pigmentado preexistente
}

Marcos Leandro Pereira', Dulcídio de Barros Moreira Júnior ${ }^{2}$

\begin{abstract}
Recurrent multifocal conjunctival melanoma originated from preexisting nevus is extremely rare: it occurs in one out of five million individuals. The investigation of this disease is extremely important due to its potential lethality. Thus, this study aims to describe a case of recurrent multifocal conjunctival melanoma originated from preexisting pigmented nevus, which occurred in the city of Patos de Minas, state of Minas Gerais. This is a case study and literature review. Histopathological diagnosis and early staging of the conjunctival lesion is a key element on how to approach the patient. The treatment procedure most commonly used today is surgical excision with adjuvant cryotherapy and mitomycin $C$. The prognosis of recurrent multifocal conjunctival melanoma originated from preexisting nevus is the worst of all ocular melanomas, with high mortality rate: $12 \%$ to $20 \%$ within 5 years and $30 \%$ within 10 years of pathological development.

Keywords: Melanoma; Conjunctival neoplasms; Melanocytic nevus; Recurrence; Amniotic membrane; Case reports
\end{abstract}

\section{RESUMO}

O melanoma conjuntival multifocal recidivado originado de nevus preexistente é extremamente raro, ocorrendo em uma pessoa para cinco milhões de habitantes. Seu estudo é de extrema relevância, devido sua potencial letalidade.Este estudo objetiva descrever um caso de melanoma conjuntival multifocal recidivado proveniente de nevus pigmentado preexistente ocorrido em Patos de Minas, MG. Este é um estudo de caso com revisão de literatura. O diagnóstico histopatológico e o estadiamento precoce da lesão conjuntival é de fundamental importância para designar a conduta frente ao paciente. O procedimento terapêutico mais utilizado nos dias atuais é a excisão cirúrgica com crioterapia adjuvante associada à mitomicina $\mathrm{C}$. O prognóstico do melanoma conjuntival multifocal recidivado originado de nevus preexistente é o pior dentre todos os melanomas oculares, apresentando alta taxa de mortalidade, $12 \%$ a $20 \%$ em 5 anos e $30 \%$ em 10 anos de desenvolvimento patológico.

Descritores: Melanoma; Neoplasias da conjuntiva; Nevo melanocítico; Recidiva; Membrana amniótica; Relatos de casos

\footnotetext{
1 Biologist, Specialist in Family and Public Health; $6^{\text {th }}$-year Medical Student at Patos de Minas University Centre (UNIPAM), Patos de Minas/ MG, Brazil.

${ }^{2}$ General Surgeon and Mentor at the Residency Programme in General Surgery, Antônio Dias Regional Hospital, Hospital Foundation of the State of Minas Gerais; Assistant Professor of Surgical Technique and Surgery I and II, Patos de Minas University Centre (UNIPAM), Patos de Minas/MG, Brazil.
}

The authors declare no conflict of interest.

Received for publication 2/8/2012 - Accepted for publication 21/1/2013 


\section{INTRODUCTION}

C onjunctival neoplasms include a broad spectrum of benign and malignant lesions, some of which can impair visual acuity or result in an aggressive malignancy that can rarely lead to death ${ }^{(1,2)}$.

A broad variety of neoplasms and pseudoneoplasms originate from the melanocytic system. Conjunctival melanoma, a rare and aggressive malignant tumour, can develop from a primary acquired melanosis, a melanocytic nevus, normal tissue, or the palpebral conjunctiva ${ }^{(3,4)}$. It can be congenital or appear in the first decades of life. It has been associated with systemic conditions such as FAM-M syndrome, xeroderma pigmentosum and neurofibromatosis; exposure to solar radiation is also considered an important risk factor ${ }^{(5)}$.

Conjunctival nevi can be pigmented or not. They are melanocytes that migrate to the sclera, the episclera or the proper substance but do not reach the epithelium. Such lesions are often multifocal and tend to recur when excised ${ }^{(6)}$.

The incidence of conjunctival melanoma is low: it affects 0.2-0.5:1.000.000 in the Caucasian population and accounts for $2 \%$ of eye tumours ${ }^{(7)}$. In a U.S. sample of 4836 melanomas, only $5.2 \%$ affected ocular structures, of which $85 \%$ affected the uvea and $4.8 \%$ the conjunctiva. In recent years its incidence has significantly increased in the male population, while remaining stable in the female population ${ }^{(8)}$.

Correct diagnosis is crucial for early excision, which is associated with a lower risk of metastasis and a lower mortality. The best diagnostic method is excision biopsy with histopathological analysis ${ }^{(9)}$.

Previous studies have noted that in cases where excision is insufficient to prevent relapse, adjuvant therapies such as cryotherapy, brachytherapy, radiation therapy, and chemotherapy can be used ${ }^{(10)}$. Moreover, it has been found that amniotic membrane transplantation can be very effective in promoting re-epithelisation of the conjunctiva by reducing postoperative inflammation, providing a substrate for limbal stem cell repopulation, and reducing scarring ${ }^{(11)}$.

The rates of recurrence of melanoma are $30-50 \%$ in 5 years, $38-51 \%$ in 10 years and $65 \%$ after 15 years, depending on the type of treatment. Excision without further treatment is associated with higher rates of recurrence. It is essential to carefully evaluate surgical margins, the type of cell and tumour thickness, as these are important indicators of prognosis ${ }^{(12,13)}$. Mortality rates are $12-20 \%$ in 5 years and $30 \%$ in 10 years $^{(11)}$.

This paper aims to describe a case of recurrent multifocal conjunctival melanoma arising from a pre-existing pigmented nevus in a patient from Patos de Minas/MG, Brazil.

This is a case report with a review of the literature. Articles were searched in the BIREME, PUBMED and MEDLINE databases using the following keywords: melanoma, cancer of the conjunctiva, melanocytic nevus, recurrence, and amniotic membrane.

\section{Case Report}

G.F.M., a married 40-year-old male working in civil construction, born in the rural areas of Presidente Olegario/MG and living in Patos de Minas/MG.

The patient was previously healthy, with no personal or family history for eye cancer. He sought ophthalmic care for the first time in 2001 complaining of eye irritation in the left eye (LE). He reported having a hypochromic macula in the left eye since birth, without any previous changes. He noted that the macula had grown in the LE limbus and its colour had changed. Thus, the patient was referred to the University Hospital of Uberlândia/MG for ophthalmic examination due to a suspicion of conjunctival melanoma.

A diagnostic biopsy was performed and pathological analysis found a multifocal conjunctival melanoma. Five excisions were then performed to extract the tumour. Chemotherapy and radiotherapy were not indicated; the patient simply underwent medical follow-up, as he had no visual disturbances.

He returned to our service for ophthalmic reassessment in 2005. Eye examination found a pigmented lesion in the LE limbus, reaching the cornea. The lesion had pigments in diffuse planes and neovascularisation. (Figure 1).

An irregular fragment of brown elastic tissue measuring $0.7 \times 0.5 \times 0.3 \mathrm{~cm}$ (Figure 2) was excised and submitted to pathological analysis (Figure 3 ), where a recurrent malignant melanoma was diagnosed. The lesion measured $2 \times 0.5 \mathrm{~mm}$ in its greatest diameter, infiltrating the chorion and compromising the deep margin. Staging was pT2 pNx PMx.

In 2008 metastases to adjacent pericorneal structures were found. The patient underwent bone scintigraphy, ultrasonography of the abdomen, chest radiograph, and additional laboratory tests, all with normal results. Another conjunctival biopsy was performed. The sample measured $0.4 \times 0.2 \times 0.1 \mathrm{~cm}$ and had a mild hyperchromic spot measuring 2 $\mathrm{mm}$ which apparently compromised one of the lateral resection margins. Pathological analysis found atypical melanocytic proliferation in the mucous membrane of the left conjunctival sac (Figure 4).

In 2011 the patient presented with a lesion in the conjunctival sac of the left eye. He underwent another excision of an ovoid, bright, brownish-yellow elastic fragment of tissue. Upon slicing the tissue measured $0.6 \times 0.4 \times 0.3 \mathrm{~cm}$, with a soft consistency and a whitish-gray colour (Figure 5). Pathologic examination diagnosed a (clinically recurrent) malignant melanoma spreading superficially and compromising the excision margins (Figure 6).

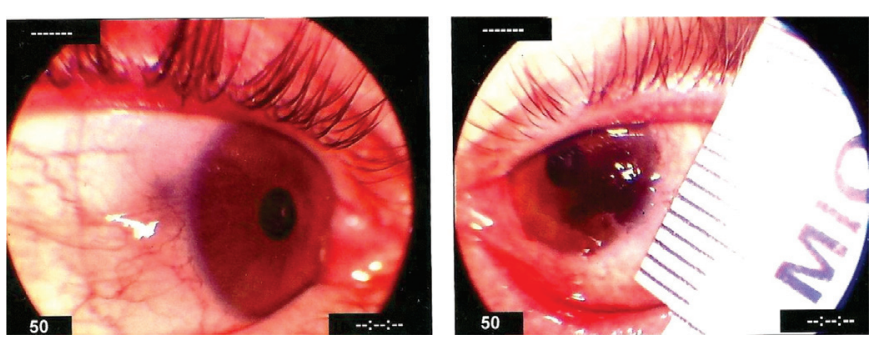

Figure 1: Digital retinography. (A) Right eye (RE): normal conjunctiva, sclera, cornea, and uvea. (B) Left eye (LE): pigmented lesion in the limbus involving the cornea with diffuse pigmented planes. Note the presence of neovascularisation.

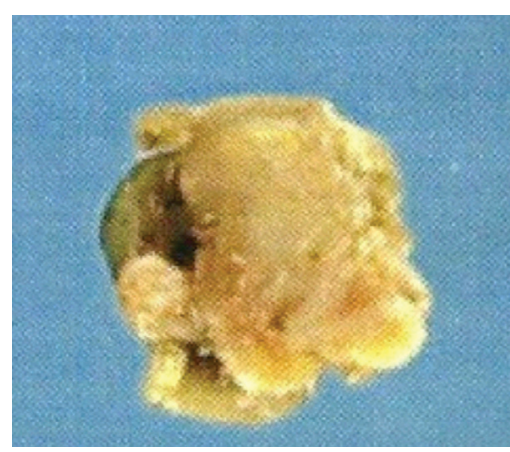

Figure 2: Lesion excised from the LE (macroscopic appearance). 


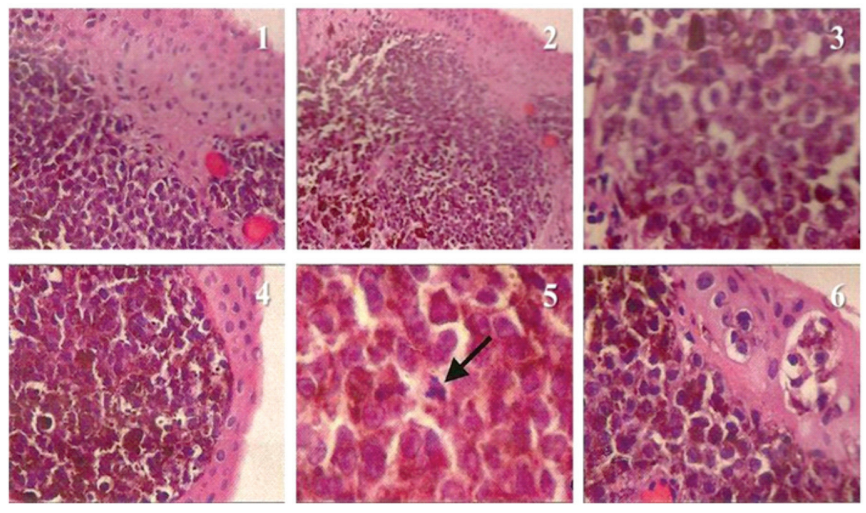

Figure 3: Histopathological analysis of the lesion after excision. Mucous membrane lined by non-keratinised stratified squamous epithelium (1) with expanded nests (2) of cells with large vesicular nuclei, prominent nucleoli (3), smooth nuclear membrane, and small cytoplasm with abundant melanin (4). Rare mitotic figures were found (5). The nests had an infiltrative aspect, extending to the upper epithelial layers (6) and the deep margin.

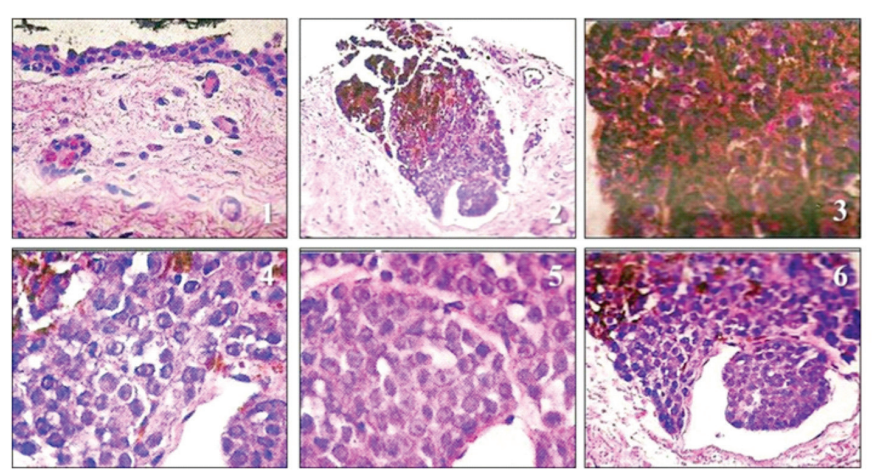

Figure 4 : Pathological analysis of the second excision. Mucous membrane of squamous epithelium without junctional melanocyte proliferation (1). Two foci of melanocytic proliferation in the stroma (2). The melanocytes had cytoplasms filled with black pigment, consistent with melanoma (3). Neoplastic cells of varying size and moderate changes in volume, with a small basophilic cytoplasm and vesicular nuclei with large nucleoli (4 and 5). In the largest focus a neoplasm was found in the lumen of a capillary vessel (6).

The patient has been undergoing ophthalmic follow-up. He was subjected to ocular surface reconstruction with amniotic membrane. He has recently reported visual impairment and diplopia and is in the process of rehabilitation. He was prescribed visual correction with $4 \mathrm{D}$ lenses and will undergo periodic clinical assessment.

\section{Discussion}

Ocular melanoma is the most common type of melanoma after skin melanoma. It affects the uveal tract and the conjunctiva ${ }^{(3)}$.

Each type of melanocyte can cause numerous types of pigmented lesions. Among those derived from dendritic melanocytes are benign pigmented melanosis, secondary acquired melanosis of the conjunctiva, and primary acquired melanosis. Lesions arising from spindle-shaped melanocytes include nevus of Ota, conjunctival nevus, and lesions deriving from nevus cells ${ }^{(14)}$.

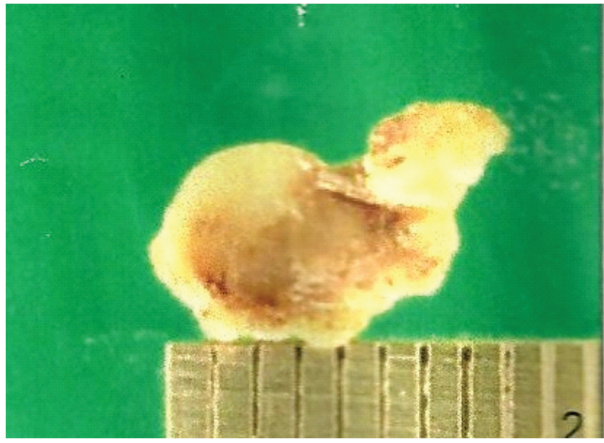

Figure 5 - Ovoid fragment excised from the left eye. (Macroscopic appearance)
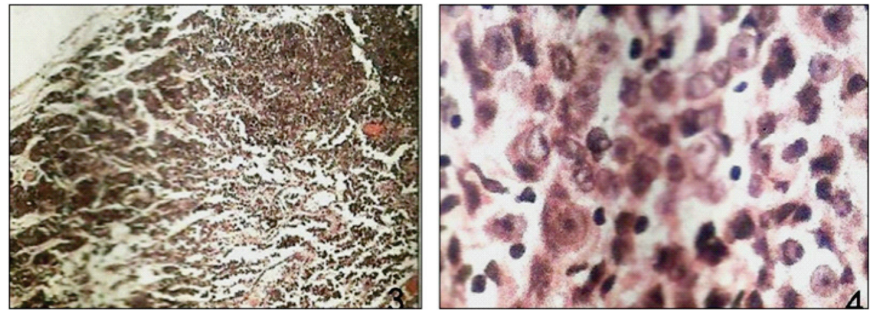

Figure 6 : Histopathological study of the third lesion: malignant neoplasm composed of nests of polygonal cells with large vesicular nuclei, prominent nucleoli, and eosinophilic cytoplasms, not very large, with indistinct margins. The blocks had adjacent infiltrative limits and loose connective tissue.

Melanoma is a malignant neoplasm with three different clinical presentations: 1) melanoma with primary acquired melanosis; 2) melanoma without primary acquired melanosis; and 3) melanoma derived from a pre-existing nevus. The latter is very rare $^{(12)}$ and is focus of this study.

Conjunctival melanomas usually arise from the $5^{\text {th }}$ decade of life, with rare cases in persons younger than 20 years. Most patients are white. Our patient was 28 years old when the disease was diagnosed, which is very rare. Tumours can recur from a preexisting nevus, most commonly from a primary acquired melanosis. Metastasis occurs to adjacent tissues, as in the case presented here, or through the lymphatic pathways ${ }^{(11)}$.

Histopathological examination of the conjunctiva is a simple procedure that provides valuable information in the study of external ocular lesions. The method can thus be considered effective, reliable, and easy to perform. Immunohistochemistry can identify the different cell types of the melanocytic system found in a lesion ${ }^{(15)}$.

In the case presented here, histopathology found polyhedral cells associated with goblet cells (Figures 3, 4 and 5). Four different cell types can be found in conjunctival melanoma: large epithelioid cells, polyhedral epithelioid cells, spindle-shaped cells, and goblet cells. Different cell types are often found within a single melanoma ${ }^{(14)}$. Melanocytic cells are highly invasive and can compromise the sclera and the episclera and extend intraocularly, as shown in Figure 6.

Initial staging in the case presented here was pT2 pNx pMx. Thus, it was a tumour of the bulbar conjunctiva occupying more than one quadrant, with $2 \mathrm{~mm}$ or less in thickness, without palpable regional lymph nodes and without metastasis. This indicates that the excised lesion was an early lesion that did not affect regional lymph nodes and did not disseminate to other tissues ${ }^{(16)}$.

The patient did not undergo chemotherapy or radiotherapy, as these methods offer no additional benefit. 
However, excision was combined with adjuvant therapy with mitomycin C. Local excision is often combined with cryotherapy; more recently, mitomycin $\mathrm{C}$ has been widely accepted as a primary treatment ${ }^{(17,18)}$.

The techniques used to improve the corneal-conjunctival interface include oral mucosa transplantation ${ }^{(19)}$, conjunctival autograft transplantation, amniotic membrane transplantation ${ }^{(20,21)}$, conjunctival transplantation associated with limbal transplantation, lamellar transplantation, and mitomycin $\mathrm{C}^{(22)}$. The main aim of conjunctival repair, beyond the healing process, is to recover the function of ocular tissue, maintaining homeostasis.

The amniotic membrane has a thick layer of collagen, a basement membrane made of laminin, and type IV collagen ${ }^{(23)}$. This composition promotes healing of persistent epithelial defects by facilitating adhesion and migration of basal epithelial cells. It also promotes angiogenesis and wound healing and has antiinflammatory and antimicrobial effects. The authors cited above believe that the amniotic membrane does not induce immune rejection because it does not express histocompatibility antigens (HLA-A, B or DR) ${ }^{(24)}$.

Different rates of relapse within 5 years have been reported such as $26 \%^{(13)}, 52 \%^{(18)}$ and $60.7 \%^{(8)}$. These differences can be explained by the fact that in some studies adjuvant therapy was used more frequently than in others.

The prognosis of recurrent multifocal conjunctival melanoma originating from a pre-existing nevus is the worst among all ocular melanomas, with a mortality rate as high as 12 $20 \%$ within 5 years and $30 \%$ within 10 years $^{(20)}$.

It should be noted that recurrent multifocal conjunctival melanoma originating from a pre-existing nevus is extremely rare, affecting one in 5 million people; however, it is important to investigate the condition due to its lethal potential. Early histopathological diagnosis and staging of conjunctival lesions is extremely important for optimal management and a good prognosis.

\section{References}

1. Kato ET, Macruz E, Morais L, Sabrosa NA, Holzchuh N, Alves MR, et al. Tumores conjuntivais: ocorrência na clínica oftalmológica da Faculdade de Ciências Médicas da Unicamp. Rev Bras Oftalmol. 1996;55(12):921-5.

2. Santo RM. Tumores conjuntivais. In: Alves MR, Kara-José N. Conjuntiva cirúrgica. São Paulo: Roca; 1999. p.125-7.

3. Shields CL. Conjunctival melanoma: risk factors for recurrence, exenteration, metastasis, and death in 150 consecutive patients. Trans Am Ophthalmol Soc. 2000;98:471-92.

4. Shields JA, Shields CL, DePotter P. Surgical management of conjunctival tumors. The 1994 Lynn B. McMahan Lecture. Arch Ophthalmol. 1999;115(6):808-15.Comment in Arch Ophthalmol. 1999;117(8):1098-9.

5. Cohen V, Papastefanou VP, Tsimpida M. Conjunctival melanocytic lesions. Ot Cet Continuing Education. May. 2011.

6. Oliveira EC, Ramos GZ, Afonso VC, Souza LB. Estudo retrospectivo da utilização do transplante de membrana amniótica em um serviço terciário de Oftalmologia. Rev Bras Oftalmol. 2008;67(4):165-71
7. Yu GP, Hu DN, McCormick S, Finger PT. Conjunctival melanoma: is it increasing in the United States? Am J Ophthalmol. 2003;135(6):800-6.

8. Missotten GS, Keijser S, De Keizer RJ, De Wolff-Rouendaal D. Conjunctival melanoma in the Netherlands: a nationwide study. Invest Ophthalmol Vis Sci. 2005;46(1):75-82.

9. Brownstein S. Malignant melanoma of the conjunctiva. Cancer Control.2004;11(5):310-6. Review.

10. Lim M, Tatla T, Hersh D, Hungerford J. Patterns of regional head and neck lymph node metastasis in primary conjunctival malignant melanoma. Br J Ophthalmol. 2006;90(12):1468-71.

11. Novais GA, Karp CL. Diagnosis and management of conjunctival melanoma [Internet]. Ophthalmic Pearls. 2010; jul/aug. Available from:http://www.aao.org/publications/eyenet/201007/upload/ 37_Pearls_FF_copy.pdf

12. Gómez Cabrera CG, Falcón Márquez I, Villamil Martínez V, Padilla González CM. Lesiones pigmentadas de párpado y conjuntiva. Rev Cuba Oftalmol. 2002;15(1):57-61.

13. Werschnik C, Lommatzsch PK. Long-term follow-up of patients with conjunctival melanoma. Am J Clin Oncol. 2002;25(3):248-55.

14. Farber M, Schutzer P,Mihm MC. Pigmented lesions of the conjunctiva. J Am Acad Dermatol. 1998;38(6 Pt 1):971-8. Comment in J Am Acad Dermatol. 2000;42(1 Pt1):145.

15. Lima CG, Veloso JC, Tavares AD, Jungman P, Vasconcelos AA. Método citológico e histopatológico no diagnóstico das lesões da conjuntiva: estudo comparativo. Arq Bras Oftalmol. 2005;68(5):623-6.

16. Furdova A, Pesko K, Strmen P, Kobzova M. Conjunctival nevus and melanoma. Bratisl Lek Listy. 2007;108(7):287-291.

17. DePotter P, Shields CL, Shields JA, Menduke H. Clinical predictive factors for development of recurrence and metastasis in conjunctival melanoma: a review of 68 cases. $\mathrm{Br} \mathrm{J}$ Ophthalmol. 1993;77(10):624-30.

18. Molgó Novell M, Salomone Bustamante C, Silva Parada P, González Bombardiere S, Flores Pérez JC. Melanoma conjuntival: reporte de un caso y revisión de la literatura. Med Cután Ibero Lat Am. 2006;34(2):71-6.

19. Siegel R. Buccal mucous membrane grafts in treatment of burns of the eye. Arch Ophthalmol. 1944;32(2):104-8.

20. Honavar SG, Bansal AK, Sangwan VS, Rao GN. Amniotic membrane transplantation for ocular surface reconstruction in StevensJohnson syndrome. Ophthalmology. 2000;107(5):975-9.

21. Kim JS, Kim JC, Na BK, Jeong JM, Song CY. Amniotic membrane patching promotes healing and inhibits proteinase activity on wound healing following acute corneal alkali burn. Exp Eye Res. 2000;70(3):329-37.

22. Golchin B, Butler TK, Robinson LP, Weichsler AW, Sutton G, Robinson DI, et al. Long-term follow-up results of lamellar keratoplasty as a treatment for recurrent pterygium and forscleral necrosis induced by beta-irradiation. Cornea. 2003;22(7):612-8.

23. Shimazaki J, Shinozaki N, Tsubota K. Transplantation of amniotic membrane and limbal autograft for patients with recurrent pterygium associated with symblepharon. $\mathrm{Br} \mathrm{J}$ Ophthalmol. 1998;82(3):235-40.

24. Tseng SC, Di Pascuale MA, Liu DT, Gao YY, Baradaran-Rafii A Intraoperative mitomycin $\mathrm{C}$ and amniotic membrane transplantation for fornix reconstruction in severe cicatricial ocular surface diseases. Ophthalmology. 2005;112(5)896-903. 